\title{
PERSEPSI PELAKU EKONOMI KULINER TENTANG SURAT REKOMENDASI MAJELIS ULAMA INDONESIA (MUI) SUMATERA BARAT PERIHAL PENGGUNAAN NAMA USAHA KULINER
}

\author{
Yogi Harian Nanda ${ }^{1}$, Elsy Renie ${ }^{2}$ \\ 1Institut Agama Islam Negeri Batusangkar \\ e-mail: yogihariann@gmail.com \\ 2Institut Agama Islam Negeri Batusangkar \\ e-mail: elsyrenie@iainbatusangkar.ac.id
}

\begin{abstract}
This study examines the perception of culinary economists on letters of recommendation from the Indonesian Ulema Council (MUI) West Sumatra regarding the probibition of culinary names that are not in accordance with Islamic law. The type of research used is field research, with exploratory qualitative methods. Sources of data in this study consisted of primary data and secondary data. The findings from this study are that the majority of producers and consumers of culinary businesses do not agree with the recommendation letter from the Indonesian Ulema Council (MUI) West Sumatra regarding the use of culinary business names and do not even care about the letter, because they consider the recommendation letter from the Indonesian Ulema Council (MUI) at the West Sumatra level. This is not a type of statutory regulation that has binding law.
\end{abstract}

Keywords: Persepsi, Pelaku Ekonomi Kuliner, Surat Rekomendasi MUI

\section{PENDAHULUAN}

Manusia merupakan makhluk sosial sekaligus individual. Maka dari itu terdapat banyak perbedaan antara individu satu dengan individu yang lainnya. Manusia tidak mungkin untuk bisa bertahan hidup tanpa berinteraksi dan berkomunikasi dengan manusia lain (Putri, 2018: 129). Karena perbedaan inilah yang menyebabkan seseorang bisa menyukai suatu objek atau tidak menyukai suatu objek. Hal tersebut tergantung dari masing-masing individu menanggapi objek dengan persepsinya.

Persepsi merupakan hasil pengamatan seseorang terhadap sesuatu hal yang ada di lingkungan sekitar melalui panca indra. Persepsi diperoleh dengan cara meringkas informasi dari seseorang dan menafsirkan informasi tersebut, sehingga seseorang tersebut dapat memberikan tanggapan mengenai baik buruknya atau positif negatifnya informasi tersebut. Persepsi pada dasarnya menyangkut hubungan antara seseorang dengan lingkunngannya melalui panca indra, setelah seseorang menginderakan objek di lingkungannya maka kemudian memproses hasil penginderaan itu, sehingga timbullah makna tentang objek tersebut (Morgan, $2002: 8$ ).

Berdasarkan hasil keputusan dan rekomendasi rapat koordinasi daerah MUI Sumatera Barat dan MUI Kabupaten se-Sumatera Barat di Bukittinggi, memutuskan bahwa hukum penggunaan nama yang tidak sesuai dengan syariah terhadap produk makanan, minuman, obat-obatan, kosmetik, dan pakaian adalah haram di dalam Islam (manhiy'anhu); (1) Kalau menyangkut hal-hal yang prinsip di dalam Islam terkait soal akidah seperti kata- kata "neraka, 
setan, iblis", maka hukum nya haram (2) Kalau terkait dengan akhlak dan etika seperti "ayam dada montok, mie caruik", maka hukumnya makruh.

Selain putusan rapat koordinasi daerah MUI Sumatera Barat se-Sumatera Barat, juga mengeluarkan rekomendasi, yaitu sebagai berikut (1) Kepada pemerintah agar melahirkan regulasi dalam impelementasi fatwa ini, (2) Kepada pemerintah agar menindak lanjuti fatwa ini bentuk imbauan dan sosialisasi kepada masyarakat, (3) Semua lapisan masyarakat agar tidak mengkonsumsi produk yang menggunakan nama-nama yang dilarang dalam fatwa ini, (4) Kepada LPOM MUI untuk tidak menerbitkan sertifikat halal terhadap produk yang menggunakan nama-nama yang tidak sesuai dengan syariat (Surat Rekomendasi MUI Padang: 2019).

Berdasarkan putusan dan rekomendasi yang telah di keluarkan oleh MUI Sumatera Barat pada tanggal 21 Juli 2019, mengenai larangan menggunakan nama-nama yang tidak sesuai dengan syariah terhadap penamaan kuliner. Pada kenyataannya masih banyak usaha yang memakai tidak sesuai dengan syariat Islam.

Syariat Islam telah mengajarkan berbagai aspek dalam menjalankan kehidupan, aspek yang diajarkan dalam Islam tidak hanya aspek dalam kehidupan bermasyarakat, tetapi juga mengajarkan aspek dalam perekonomian. Sesuai dengan fatwa-fatwa yang dihasilkan Majelis Ulama Indonesia (MUI) adakalanya menimbulkan kontroversi di tengah-tengah masyarakat, ada pula yang memandangnya sebagai corong penguasa, dan ada pula masyarakat yang menilainya sebagai tidak konsisten. Munculnya respon seperti itu dari masyarakat sangat erat kaitannya dengan kurangnya pengetahuan masyarakat terhadap konsep ijtihad Majelis Ulama Indonesia (MUI) serat ciri-ciri hukum Islam yang dijadikan acuan oleh Majelis Ulama. Indonesia (MUI) dalam menghasilkan suatu fatwa. Oleh sebab itu, studi dalam ini dirasa amat perlu dilakukan

Kegairahan dan kerinduan akan perlunya Majelis Ulama Indonesia ini mulai menunjukkan titik-titik kelahirannya melalui usaha mengintensifkan kegiatan, di antaranya berupa daerah upaya menggairahkan kegiatan Majelis Ulama Indonesia yang sudah ada di berbagai daerah. Menteri Dalam Negeri menginstruksikan supaya membentuknya secepat mungkin. Pada bulan Mei 1975, di seluruh Daerah tingkat I dan sebagai daerah tingkat II Majelis Ulama sudah terbentuk, sedangkan di pusat dibentuk pula suatu Panitia Persiapan Musyawarah Nasional yang diketuai oleh H. Kafrawi, MA yang bertujuan menyiapkan materi kegiatan serta tema musuawarah (MUI, 2011: 33-35).

Fungsi MUI sesuai dengan Munas I, pertama, memberikan fatwa dan nasehat mengenai masalah keagamaan dan kemasyarakatan kepada pemerintah dan umat Islam umumnya sebagai amal ma'ruf nahi munkar, dalam usaha meningkatkan ketahanan Nasional. Kedua, memperkuat ukhuwah Islamiyah dan melaksanakan kerukunan antar umat beragama dalam mewujudkan persatuan dan kesatuan Nasional. Ketiga, mewakili umat Islam dalam konsultasi antar umat beragama. Keempat, penghubung ulama dan umara (pemerintah) serta jadi penerjemah timbal balik antara pemerintah dan umat guna menyukses pembangunan Nasional. Kelima, Majelis Ulama tidak berpolitik dan tidak operasional (MUI, 2011: 38). Agar hubungan manusia berjalan dengan baik dan optimal, maka Allah swt menentukan 
aturan dalam membina hubungan tersebut berupa syari'ah di bidang muamalah yang dikenal dengan fikih muamalah, yaitu aturan-aturan Allah yang ditujukan untuk mengatur kehidupan manusia dalam urusan dunia dan sosial kemasyarakatan (Nurhasanah, 2010: 286).

Dalam kehidupan, manusia tidak akan mampu untuk menunaikan kewajiban spritual (ruhiyah), dan material (maliyah) tanpa terpenuhinya kebutuhan primer seperti makanan, tempat tinggal dan keamanan. Salah satu yang diajarkan oleh Islam yaitu dalam berdagang, yang sering juga disebut dengan mencari anugerah dari Allah (Abdullah, 2011: 10). Oleh karena itu, pebisnis syariah dituntun agar aktivitas ekonomi yang ditekuninya selalu berorientasi ada mencari redha Allah semata sebagaimana yang dimaksud dalam firmanAllah yaitu pada surat Q.S Al-An'am ayat 162-163 yang dapat diambil kesimpulannya, bahwa kita sebagai umatmanusia melakukan kewajiban yang diperintahkan oleh Allah SWT, dan umat manusia juga kembali kepada Allah SWT. Oleh karena itu manusia hendaknya senantiasa bersyukur kepada Allah SWT yang telah memberikan kenikmatan kepada umat manusia.

Salah satu bentuk kegiatan kemudahan bagi umat manusia yaitu adalah bermu'amalah, mu'amalah adalah kegiatan untuk memenuhi segala sesuatu yang berhubungan dengan kebutuhan kehidupan sehari-hari manusia sebagai makhluk sosial (Kurnia, 2018: 17). Bermu'amalah juga sering disebut atau dikenal oleh masyarakat yaitu dengan berdagang.

Kegiatan berdagang atau muamalah pada dasarnya adalah boleh dilakukan, tergantung dengan rukun atau syarat yang nantinya dapat membuat kegiatan tersebut menjadi sah atau batal. Selain itu dalam syariat Islam juga ada ketentuan halal dan haram, yaitu boleh atau dilarangnya suatu yang kita dapatkan tersebut.

Menurut Hendi Suhendi bahwa perdagangan atau jual beli adalah suatu perjanjian tukar menukar benda atau barang yang mempuyai nilai secara sukarela antara kedua belah pihak, yang satu menerima benda-benda dan pihak lain menerimanya sesuai dengan perjanjian atau ketentuan yang tela dibenarkan syara' dan disepakati (Suhendi, 2008: 68-69).

Berdasarkan fenomena yang ada pada saat sekarang ini, penulis melihat bahwa keputusan dan rekomendasi MUI (Majelis Ulama Indonesia) Sumatera Barat tentang penggunaan nama-nama yang tidak sesuai dengan syariah terhadap produk makanan, minuman, obat-obatan, kosmetik, dan pakaian dianggap oleh masyrakat atau pelaku ekonomi kuliner hanyalah sebagai sebuah surat edaran yang tidak harus dipatuhi dan masih banyak masyarakat atau pelaku kuliner masih banyak yang melanggar putusan tersebut.

Salah satunya adalah hasil observasi yang penulis lakukan dengan produsen Mie Bangcat Lima Kaum mengatakan bahwa, beliau menyetujui Surat Keputusan dan

Rekomendasi Majelis Ulama Indonesia tingkat Sumatera Barat tersebut, tetapi beliau menganggap bahwa tidak ada permasalahan dalam penamaan dari usahanya selagi bertujuan untuk mencari rezekiyang halal dan mengaharap ridha dari Allah SWT (Lisnawati, Wawancara, Mie Bangcat Lima Kaum, 16 September 2019).

\section{METODE PENELITIAN}

Penelitian ini adalah penelitian lapangan field research yang penulis lakukan tentang 
Persepsi Pelaku Ekonomi Kuliner tentang Fatwa MUI Sumatera Barat perihal penggunaan Nama Usaha Kuliner. Sumber Data yang penulis lakukan ada yaiu sumber data Data primer yang diperoleh dari pelaku kuliner dan konsumen di Tanah Datar, Padang Panjang, Bukittinggi dan Padang yang menggunakan nama-nama yang bertentangan dengan syari'at agama Islam. Teknik pengumpulan data dilakukan dengan wawancara disusun secara sistematis dan lengkap untuk mengumpulkan data. Setelah itu juga diambil sumber-sumber relevan yang dapat memberikan informasi secara valid dan kemudian ditarik suatu kesimpulan (Putri, 2020: 132).

\section{HASIL DAN PEMBAHASAN}

\section{A. Persepsi Pelaku Ekonomi Kuliner Sebagai Produsen Terhadap Penamaan Usaha Makanan dan Minuman Yang Tidak Sesuai dengan Syariat Islam di Sumatera Barat}

Berdasarkan hasil temuan di lapangan dengan beberapa pelaku ekonomi kuliner yang membuka usaha di Lima Kaum Batusangkar, Saruaso, Bukittinggi, Padang Panjang dan Padang, hasil temuan peneliti terhadap pelaku usaha tidak memberikan penamaan usaha kulinernya sesuai dengan syariat Islam. Padahal hal-hal terkait penamaan nama usaha kuliner telah diatur dalam putusan fatwa MUI Sumatera Barat tentang pengharaman nama kuliner yang tidak sesuai syariat Islam. Data tentang penamaan kuliner tentang fatwa MUI, diperoleh melalui wawancara yang dilakukan dengan 6 orang informan penelitian yaitu pelaku ekonomi sebagai produsen Mie Narko, Mie Bangcat dan Ceker Setan.

Berdasarkan wawancara yang peneliti lakukan dengan informan I yaitu dengan produsen Mie Narko Saruaso, motivasi mengenai penamaan terhadap kulinernya bahwa sekarang ini konsumen banyak tertarik dengan nama yang unik dan karena keunikan nama tersebut konsumen tertarik untuk mencoba dan mencari tahu tentang apa itu Mie Narko. Kuliner yang di bangun ini cukup diminati oleh kalangan masyarakat terutama golongan pelajar dan mahasiswa. Kuliner Mie Narko sangat booming di daerah ini, karena peminat yang begitu banyak dan rasa yang membuat konsumen katagihan. Untuk memenuhi standar kehalalan namanya saya rasa belum, karna apa arti sebuah nama. Akan tetapi untuk bahan makanannya Insya Allah menggunakan bahan yang halal.

Berdasarkan wawancara dengan informan II yaitu produsen Mie Bangcat Lima Kaum, mengatakan bahwa motivasi ia memberi nama kuliner ini dengan Mie Bangcatkarena dilihat pada sekarang ini, konsumen lebih tertarik kepada yang namanya keunikan dan ingin untuk mencobanya. Untuk pemenuhan standar kehalalannya produsen juga kurang paham, karena hanya mengikuti trend. Akan tetapi, untukkehalalan bahan makanannya, Insya Allah halal dan dengan bahan-bahan makanan yang halal. Produsen tidak mengetahui tentang adanya fatwa MUI mengenai penamaan terhadap kesesuaian nama kuliner ini dengan nama Syari'at Islam. Penamaan Mie Bangcat hanya untuk menarik minat dari konsumen saja. Menurutnya hanya sekedar nama untuk mempopulerkan kuliner ini, tidak akan jadi masalah.

Untuk pengaruh terhadap penghasilan dari kuliner ini sangatlah berpengaruh. Karena keunikan nama tersebut, Mie Bangcat ini dikenal oleh banyak masyarakat dan memberikan 
untung yang sesuai dengan yang diharapkan. Apabila nama Mie Bangcatini diganti dengan nama yang sesuai dengan Syari'at Islam, tidak masalah. Karena masyarakatpun sudah mengetahui dengan khas dan rasa yang dimiliki, begitupun dengan tempatnya (Ibu Rosniati, Wawancara Pribadi, Lima Kaum, 24 Februari2020)

Berdasarkan hasil wawancara dengan informan III dengan produsen Ceker Setan yang beralamat di Bukittinggi, menurut produsen motivasi penamaan Ceker Setan mengikuti perkembangan yang terjadi saat ini, para konsumen lebih menyukai hal-hal yang unik dan menarik dibanding penamaan kuliner biasa. Ceker Setan disajikan dalam beberapa tingkatan atau level kepedasan yang berbeda-beda. Mengenai standar kehalalan, produsen berpendapat kulinernya telah memenuhi standar halal karenadiproses dan dimasak dengan menggunakan cara dan bahan-bahan yang halal. (Lisnawati, Wawancara Pribadi, Bukittinggi, 25 Februari 2020)

Berdasarkan wawancara dengan Informan IV produsen Mie Narko Bukittinggi dengan jawaban yang masih sama dengan sebelumnya yaitu motivasi penamaan kuliner Mie Narko berdasar kepada trend yang banyak diminati para anak sekolah dan mahasiswa. Pemilihan produk yang halal menjadi alasan bahwa kulinernya telahmemnuhi standar kehalalan. Terkait dengan fatwa MUI, produsen telah mengetahui bahwa penggunaan nama kuliner yang tidak sesuai syariat Islam tidak boleh digunakan, namun ia tetap berkomitmen penamaan kulinernya hanya sekedar memberikan kesan keunikan dan menggambarkan rasa kepedasan saja. Penamaan kuliner Mie Narko sangat berpengaruh terhadap penghasilannya, namun jika harus berganti nama ia bersedia karena masyarakat telah mengetahui tentang rasa kulinernya (Alvian, Wawancara Pribadi, Bukittinggi, 25 Februari 2020).

Berdasarkan wawancara dengan Informan $\mathrm{V}$ yang telah peneliti lakukan dengan produsen Mie Narko Padang panjang, tidak jauh berbeda dengan hasil sebelumnya. Produsen menjawab motivasi penamaan usaha kulinernya berdasarkan keunikan namayang disukai banyak kalangan, terutama pelajar dan mahasiswa. Usaha kuliner yang dijalankan menggunakan produk/bahan-bahan yang halal sehingga memenuhi standar kehalalan. Produsen mengetahui bahwa penamaan kulinernya tidak sesuai dengan putusan fatwa MUI Sumatera Barat, namun ia beralasan penamaan tersebut hanya melambangkan suatu kepedasan yang terdiri dari level kepedasan tersendiri.Penamaan nama yang unik seperti Mie Narko ini sangat mempengaruhi hasil penjualan namun jika harus mengganti nama kuliner tidak masalah karena masyarakattelah mengenal rasanya (Febi Halim, Wawancara Pribadi, Padang Panjang, 27 Februari 2020).

Berdasarkan hasil wawancara dengan informan VI produsen Mie Narko Padang, motivasi penamaan kuliner tidak jauh berbeda dari jawaban sebelumnya yaitu termotivasi karena kalangan masyarakat lebih menyukai keunikan. Penggunaan bahan-bahan dalam kuliner ini menggunakan bahan yang halal sehingga memenuhi standar kehalalannya.

Produsen mengetahui tentang fatwa MUI terkait penamaan kuliner yang tidaksesuai syariat Islam tidak boleh digunakan, namun ia beralasan penamaan hanyasebagai lambang kepedasan kulinernya. Penggunaan nama kuliner yang unik sangat berpengaruh dalam penghasilannya, sehingga jika harus mengganti nama kulinernya ia tidak setuju karena akan 
mempengaruhi pemasukannya dari hari kehari (Tari Utami, Wawancara Pribadi, Padang, 29 Februari 2020).

Berdasarkan hasil wawancara di atas dapat disimpulkan bahwa masih banyak pelaku ekonomi kuliner yang masih melanggar surat rekomendasi Majelis Ulama Indonesia (MUI) Sumatera Barat tentang pengguanaan nama usaha kuliner karena pelaku usaha ekonomi kuliner tersebut mengetahui surat rekomendasi Majelis Ulama Indonesia (MUI) Sumatera Barat tentang pemggunaan nama usaha kuliner tersebutdan tidak memperdulikan isi surat rekomendasi MUI Sumatera Barat tersebut.

\section{B. Persepsi Pelaku Ekonomi Kuliner Sebagai Konsumen Terhadap Penamaan Usaha Makanan dan Minuman Yang Tidak Sesuai dengan Syariat Islam di Sumatera Barat}

Selain wawancara dengan produsen, peneliti juga menggali informasi dari konsumen kuliner dengan penamaan yang unik ini. Berikut adalah hasil wawancara yang peneliti lakukan dengan 15 orang konsumen penikmat kuliner Mie Narko, Mie Bangcat dan Ceker Setan tersebut.

Berdasarkan wawancara yang dilakukan dengan informan I konsumen Mie NarkoLima Kaum Batusangkar, dengan saudari Yuni Sartika. Menurutnya penamaan kuliner ini menggunakan nama yang unik sehingga ia penasaran ingin mencoba rasanya, begitupun dengan teman-temannya yang ingin sekali untuk mencobanya. Karna dari temannya yang lain mengatakan bahwa tidak hanya dengan nama yang unik, rasanya juga memiliki keunikan tersendiri, sehingga Tika dan teman-temannya lebih sering membelinya dan membuatnya ketagihan. Tidak hanya itu, Mie Narko ini juga memiliki tingkat kepedasan yang sesuai dengan selera anak sekolahan.

Mengenai keputusan fatwa MUI terkait penamaan kuliner ini ia tidak mengetahuinya. Karena penasaran dan rasa ingin tahu dengan rasa kulinernya, ia tidakmengetahui bahwa kuliner yang di makannya menurut keputusan MUI tidak sesuai dengan nama syari'at Islam. Dan jika nama kuliner ini diganti dengan nama yang sesuai dengan syari'AT Islam, lebih baik menurutnya, akan tetapi bagaimana dengan pemilik kuliner tersebut. Untuk dampak terhadap kesehatannya tidak berpengaruh, karna bahan yang digunakan berasal dari bahan yang halal, sehingga tidak berpengaruh terhadap kesehatanya. Akan tetapi ada temannya yang tidak biasa dengan pedasnya dan baru mencoba, sehingga menyebabkan diare atau sakit perut. (Yuni Sartika, Wawancara Pribadi, Limo Kaum, 22 Februari 2020)

Berdasarkan wawancara yang dilakukan dengan informan II konsumen Mie Narko Lima Kaum Batusangkar, dengan saudari Nila Febria Ningsih. Menurutnya penamaan terhadap kuliner ini tidak sesuai dengan nama Islam. Nama kuliner ini mengandung penamaan yang haram karna menggunakan Narko. saudari Nila sangat tidak tertarik dengan penamaan kuliner ini, ia berada di tempat ini karna menemani temannya yang sangat suka dengan kulliner ini, begitupun dengan kepedasan yang dimiliki kuliner ini sesuai dengan selera temannya.

Untuk keputusan MUI mengenai penamaan kuliner ini, karna ia mengetahuitentang keputusan MUI dengan pengharaman nama kuliner yang tidak sesuai dengan syari'at Islam. 
Hal ini lah yang membuatnya tidak tertarik untuk mencobanya. Dan ia pun menyetujui dengan keputusan MUI tentang pengharaman nama kuliner yang tidak sesuai dengan syari'at Islam. Karna takutnya pegadang memanfaatkan nama yang haram tersebut untuk mengais keuntungan yang besar, padahal di dalam rezekinya terdapat penghasilan yang kurang berkah. Untuk pergantian nama terhadap kuliner ini, saudari Nila sangat menyetujuinya. Agar mendapatkan penghasilan yang berkah dan diridhoi oleh Alah Swt. Sebaiknya diganti dengan nama yang sesuai dengan syari'at Islam, akan tetapi bagaimana dengan pedagangnya? Dampak terhadapkesehatan temannya, ia tidak mengetahuinya. Akan tetapi, dilihat temannya yang sukakuliner ini sama sekali tidak berpengaruh terhadap kesehatannya. Sebaliknya ada lagi temannya yang tidak cocok dengan kuliner ini mengalami diare dan muntah-muntah (Nila Febria Ningsih, Wawancara Pribadi, Limo Kaum, 22 Februari 2020).

Berdasarkan wawancara yang dilakukan dengan informan III konsumen Mie Bangcat Saruaso dengan saudari Annisa Fitri. Menurutnya penamaan terhadap kulinerini tidak sesuai dengan syari'at Islam. Akan tetapi kuliner ini memiliki nama yang unik dan rasa yang khas sesuai dengan selera, karna saudari Annisa sangat suka dengan rasa yang pedas begitupun dengan tingkat kepedasan yang dimiliki kuliner ini.Hal inilah yang membuat saudari Annisa tertarik pada kuliner ini meskipun ia mengetahui bahwa nama kuliner Mie Bangcat ini tidak sesuai dengan syari'at Islam.

Mengenai keputusan MUI tentang penamaan terhadap kuliner yang tidak sesuai dengan syari'at Islam, ia mengetahuinya. Ia beranggapan bahwa bahan-bahan yang digunakan menggunakan bahan yang halal, sehingga ia tidak setuju dengan keputusanMUI. Menurutnya, apalah arti dari sebuah nama, sedangkan bahan yang digunakan berasal dari bahan-bahan yang halal. Nama kuliner ini hanya berfungsi untuk menarik perhatian pembelinya saja, jadi tidak ada yang salah dengan nama kuliner ini. Iya kuliner ini menggunakan kata Bangcat, tapi bukan makanannya yang Bangcat.

Untuk pergantian nama terhadap penamaan kuliner ini, ia tidak setuju. Menurutnya tidak ada yang salah dengan namanya, akan tetapi jika ada UU yang mengatur tentang pergantian nama terhadap nama yang tidak sesuai dengan syari'at Islam, lebih baik diganti. Karna Negara kita ini adalah Negara Hukum. Sedangkan untuk pengaruh terhadap kesehatannya, sama sekali tidak ada pengaruhnya. Menurutnya bahan yang digunakan berasal dari bahan yang halal, karna hal tersebut lah yang membuat tidak adanya dampak/ pengaruh terhadap kesehatannya. (Annisa Fitri, Wawancara Pribadi, Saruaso, 24 Februari 2020)

Sementara itu informan IV selaku konsumen Mie Bangcat Saruaso juga dengan saudara Malik Maulana mengatakan bahwa nama terhadap kuliner Mie Bangcat ini sangat unik dan menarik sehingga Malik berkeinginan untuk mencobanya. Dan juga kuliner ini memiliki rasa dan selera yang sesuai dengan keinginan. Tingkat kepedasanyang dimilikinya pun sangat sesuai dengan kepedasan yang diinginkannya karnaMalik menyukai pedas dan suka dengan tantangan pedas.

Mengenai keputusan fatwa MUI tentang penamaan terhadap kuliner yang tidak sesuai dengan syari'at Islam, Malik sama sekali tidak mengetahuinya. Jika saja ia mengetahuinya dari dulu, ia tidak akan pernah lagi untuk mencobanya. Untuk pergantian terhadap nama yang 
tidak sesuai dengan syari' at Islam lebih baik diganti agar rezeki yang diterima menjadi berkah. Akan tetapi itu semua tergantung kepada pemiliknya, karna ia hanyalah seorang pembeli dan bukan penjual dan ia juga tidak berhak untuk melakukan pergantian terhadap penamaan kuliner tersebut. Dan untuk dampak terhadap kesehatannya sama sekali tidak ada pengaruhnya, karna ia sudah berlangganan dengan kuliner ini. Karna bahan yang digunakan berasal dari bahan yang halal, itulah yang menyebabkan tidak adanya dampak terhadap kesehatannya (Malik Maulana, Wawancara Pribadi, Saruaso, 24 Februari 2020).

\section{Persepsi Pelaku Ekonomi Kuliner sebagai Produsen dan Konsumen Tentang Fatwa MUI Sumatera Barat Perihal Penamaan Nama Usaha Kuliner}

Berdasarkan hasil temuan di lapangan, beberapa pelaku ekonomi kuliner terutama produsen tidak memberikan penamaan usaha kulinernya sesuai dengan syariat Islam. Padahal hal-hal terkait penamaan nama usaha kuliner telah diatur dalam putusanfatwa MUI Sumatera Barat tentang pengharaman nama kuliner yang tidak sesuai syariat Islam. Persepsi produsen sebagai pelaku ekonomi kuliner terkait penamaan kulinernya hanya berdasar kepada keunikan nama untuk menarik pelanggan saja, produsen tidak memperdulikan putusan fatwa MUI tersebut meskipun mereka telah mengetahui tentang adanya pengharaman nama kuliner yang tidak sesuai syariat Islam, karena menurut mereka itu hanya sebuah nama kuliner yang tidak ada hubungannya dengan syariat Islam, sedangkan untuk semua bahan-bahan baku yang digunakan dijamin menggunakan bahan yang semuanya halal.

Melihat persepsi pelaku ekonomi sebagai konsumen atau penikmat kuliner. Masih banyak yang tidak memperdulikan surat rekomendasi Majelis Ulama Islam (MUI) bahkan tidak mengetahui bahwa MUI mengeluarkan fatwa pengharaman nama kuliner yang tidak sesuai syariat Islam ini. Bagi sebagian yang mengetahui namun tidak memperdulikan hanya menyampaikan pendapat bahwa penamaan kuliner seperti Mie Narko atau Mie Bangcat merupakan ciri khas dari kuliner tersebut, sedangkan untuk rasa sangat cocok dengan para konsumen pecinta makanan pedas, terutama parapelajar dan mahasiswa karena harga kuliner yang enak, murah dan sesuai dengan kantong para pelajar tersebut. Bagi konsumen yang menyukai kuliner ini tidak memperdulikan pengharaman nama kuliner sebagaimana putusan dalam surat rekomendasi Majelis Ulama Islam (MUI), yang penting rasa kuliner enak dan murah serta menggunakan bahan-bahan yang halal untuk dimakan, sehingga menjadi produk halal untuk dikonsumsi.

Terkait hasil temuan di lapangan yang telah dipaparkan di atas, menurut Yusuf Qardhawi pada asalnya hukum dari sesuatu adalah boleh dan tidak haram, sebagaimana maksud yang terkandung kaidah fikih berikut ini:

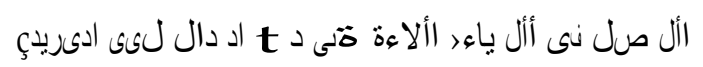

Artinya: "Hukum asal dari sesuatu adalah mubah sampai ada dalil yang melarangnya (memakruhkanya atau mengharamkannya)". (Imam As-Suyuthi, dalam al Asyba'wan Nadhoir : 43).

Dalam kaidah tersebut dapat dipahami bahwa segala sesuatu pada asalnya hukumnya boleh dan tidak haram, kecuali ada dalil nash sahih (benar) dan sarih (jelas) yang menunjukkan atas keharamannya, apabila tidak ada dalil nash dalam penunjukkan keharamannya maka 
kembali pada hukum asalnya yaitu halal (Thobieb, 2003: 94-95).

Dalam Islam mengkonsumsi makanan tidak hanya mengedepankan konsep halal namun juga baik (tayyib), menurut syara' makanan yang baik (ath-ta'am ath-tayyib)berarti sesuatu yang boleh dimakan, baik dari sisi zat, ukuran, maupun tempat, Hijazimengartikan kata tayyibat sebagai sesuatu yang suci dari shubhah (Kadar, 2011: 144).Selain makanan dan minuman yang halal dan haram, ada juga makanan dan minuman yang subhah, subhah merupakan perkara yang tidak dijelaskan halal danharamnya oleh syariat (Faiza, 2019: 42). Dalam hal ini sebagian ulama mengatakan selama suatu perkara tidak ada penjelasan halal dan haram maka dikembalikan kehukum asal yaitu mubah (boleh) kecuali bila ada dalil yang mengharamkannya (Aziz, 2013: 1077).

Penetapan kehalalan suatu produk untuk dikonsumsi itu sendiri telah diatur dalamsurat rekomendasi Majelis Ulama Islam (MUI) Sumatera Barat tentang penetapan produk halal, diantaranya (a). Keharusan mengkonsumsi makanan yang halal sesuai dengan firman Allah SWT dalam QS.Al-Baqarah ayat 168 yang maksudnya adalah Allah SWT telah berfirman bahwa konsumsi lah makanan yang halal dan baik yang ada di bumi, jangan mengikuti langkah-langkah syaitan, namun para pelaku ekonomi lebih memilih menggunakan nama syaitan untuk menarik para pelanggannya, (b) Kehalalan makhluk Allah secara umum, (c) Beberapa jenis makanan dan minuman yang diharamkan, seperti bangkai, daging babi, hewan yang disembelih tanpa menyebut nama Allah, (d) Kehalalan dan keharaman sesuatu yang dikonsumsi menurut hadits, (e) Sesuai dengan kaedah fiqh.

Berdasarkan fatwa yang disebutkan di atas, faktanya yang terjadi saat ini kalangan produsen kuliner di Sumatera Barat lebih mengutamakan kepada penamaan kuliner yang unik dan lebih menarik hati pelanggan. Persepsi pelaku ekonomi baik itu produsen maupun konsumen tidak memikirkan apa makna dari penamaan kuliner tersebut. Pelaku ekonomi hanya lebih mengejar keuntungan dan cita rasa dari kuliner tersebut dibanding dengan unsur haram yang terkandung dalam penamaan kuliner yang dipasarkan.

Hal ini juga tidak sesuai dengan standardisasi halal yang yang di tetapkan Rekor komisi Fatwa dan LP POM serta Departemen Agama RI, pada tanggal 25 Mei 2003 di tetapkan fatwa tentang standardisasi fatwa halal yang menjelaskan bahwa:

a. Tidak boleh mengkonsumsi dan menggunakan nama dan/atau simbol-simbol makanan/minuman yang mengarah kepada kekufuran dan kebatilan.

b. Tidak boleh mengkomsumsi dan menggunakan nama dan/atau simbol-simbol makanan/minuman yang mengarah kepada nama benda/binantang yang diharamkan terutama babi dan khamar, kecuali yang telah mentradisi ( $\left.u r f f^{\prime}\right)$ dan dipastikan tidak mengandung unsur-unsur yang diharamkan, seperti nama bakso, bakmi, bakwan, bakpia, dan bakpao.

c. Tidak boleh mengsumsi dan menggunakan bahan campuran bagi kompunen makan/minuman rasa/aroma (flafour) benda-benda atau binatang yang diharamkan seperti mie instan rasa bacon flavour, dll

d. Tidak boleh mengkomsumsi makanan dan minuman yang menggunakan nama-nama makanan/minuman seperti whisky, brandy, beer, dll. 
Setelah MUI Sumatera Barat memaparkan dengan sangat jelas standar penamaan usaha kuliner yang memiliki beberapa syarat terutama tidak boleh menggunakan nama diharamkan seperti yang mengarah pada simbol-simbol kepada nama binatang atau benda yang diharamkan. Berdasarkan putusan surat rekomendasi yang telah dikeluarkan Majelis Ulama Indonesia Sumatera Barat tentang pengharaman nama usaha kuliner yang tidak sesuai syariat Islam, jika kita bandingkan penerapan di lapangan, terdapat beragam persepsi pelaku ekonomi, di antaranya: (a) pelaku ekonomi yang tidak mau mematuhi peraturan yang telah dibuat oleh MUI Sumatera Barat, (b) pelaku ekonomi yang tidak memperdulikan surat rekomendasi Majelis Ulama Islam (MUI) Sumatera Barat, (c) pelaku ekonomi yang hanya mengedepankan tentang cita rasa dan ciri khas dibandingkan penghalalan nama usaha kuliner itu sendiri, (d) pelaku ekonomi yang merasa keputusannya sendiri benar, tidakpeduli dengan pengharaman nama usaha kuliner karena bahan-bahan yang digunakannya halal.

\section{KESIMPULAN}

Berdasarkan hasil penelitian "Persepsi Pelaku Ekonomi Kuliner Tentang Surat Rekomendasi Majelis Ulama Islam (MUI) Sumatera Barat Perihal Penggunaan Nama Usaha Kuliner", dapat ditarik kesimpulan bahwa mayoritas produsen dan konsumen usaha kuliner tidak meyetujui ada surat rekomendasi Majelis Ulama Indonesia (MUI) Sumatera Barat tentang perihal penggunaan nama usaha kuliner dan bahkan tidak memperdulikan surat tersebut, karena mereka menganggap surat rekomendasi Majelis Ulama Indonesia (MUI) tingkat Sumatera Barat tersebut merupakan bukan jenis peraturan perundang-undangan yang mempunyai hukum mengikat.

\section{DAFTAR PUSTAKA}

Abdillah,A.,Dkk. (2019). Lembaga Quasi Non Govermental Organization (QUANGO) Dalam Sistem Ketatanegaraan Indonesia: Majelis Ulama Indonesia. Jurnal Hukum \&Pembangunan Volume 49 No : 110-135.

Abdullah, M. (2011). Wirausaha Berbasis Syariah. Antasari Press: Banjarmasin.

Ahmad H,R. (2012). Etika Bisnis Islami, dalam http://www.etika bisnis dalam Islam.Info.html di akses pada tanggal 30 Oktober 2019.

Ali, M. (2016). Konsep Makanan Halal Dalam Tinjauan Syariah Dan Tanggung Jawab Produk Atas Produsen Industri Halal. Jurnal Ahkam No. 2 Vol. XVI 35.

Amin, M. (2015). Himpunan Fatwa Majelis Ulama Indonesia Dalam Bidang Pom Dan Iptek. Jakarta: Erlangga.

Arfan Lubis Ikhsan. (2011). Akuntansi Keperilakuan. Jakarta: Salemba Empat.

Atsar, A., dkk. (2019). Buku Ajar Hukum Perlindungan Konsumen. CV. Budi Urama.

Badroen, Faisal. 2006. Etika Bisnis Dalam Islam. Jakarta: Kencana.

Bagian Proyek Sarana Dan Prasarana Produk Halal Direktorat Jenderal Bimbingan Masyarakat Islam Dan Penyelenggaraan Haji. Sistem Dan Prosedur Penetapan Fatwa Produk Halal 
Majelis Ulama Indonesia. Departemen Agama RI, (2003) : Jakarta.

Besra, Eri. (2012). Potensi Wisata Kuliner dalam Mendukung Pariwisata di Kota Padang.

Dahwal, S. (2019). Etika Bisnis Menurut Hukum Islam (Suatu Kajian Normatif). Diakses Dari Http:/ / Repository.Unib.Ac.Id/483/1/1-

JUDUL\%20ETIKA\%20BISNIS\%20DALAM\%20ISLAM.Pdf. Pada Tanggal 23 November 2019.

Dewi, F.,dkk. (2013). Perilaku Konsumen. Palembang: Citrabooks

Dita Wahyu Ningtyas. (2017). Korelasi Faktor Pembentuk Persepsi dengan Persepsi Konsumen terhadap Media Pemasaran Online. Jurnal Sustainable Agriculture Vol. 32 No. 2 Tahun 2017.

Djakfar, Muhammad. (2007). Etika Bisnis Dalam Perspektif Islam. Malang: UIN Malang Press. Jurnal Riset Akuntansi dan Bisnis Vol. 12 No. 1 Tahun 2012

Faiza, S,N. (2019). Analisis Hukum Islam Dan Undang-Undang No 33 tahun 2014 Terhadap Penolakan Sertifikasi Label Halal MUI Surabaya Pada Produk Mie Setan. Skripsi. Universitas Negeri Sunan Ampel. Surabaya.

Hendi S. (2008). Fiqh Muamalah. Jakarta: Raja Grafindopersada.

Harry D, T. (1980). International Product Liability, Sijthoff \& Noordhaff International Publishers. Netherland.

Kadar,M, Y. (2011). Tafsir Ayat Ahkam Tafsir Tematik Ayat-Ayat Hukum. Amzah: Jakarta.

Kawasati, K. (23 November 2019) Etika Bisnis Dalam Perspektif Islam. Diakses Dari https://Www.Academia.Edu/38218608/Etika_Bisnis_Dalam_Perspektif_Islam._Docx Pada Tanggal 23 November 2019.

Keraf, S. (1998). Etika Bisnis (Tuntutan Dan Relevansinya). Kanisius: Yogyakarta

Komisi Fatwa MUI Tentang Penetapan Produk Halal Di Akses Dari Http://Halalmu Pada Tanggal 25 November 2019.

Kurnia, K. (2018). Tinjauan Hukum Islam Tentang Jual Beli Makanan Dengan Sebutan NamaNama Aneh (Studi Di Bandar Lampung). Skripsi. Universitas Raden Intan Lampung. Lampung.

Moleong, L,J. (2006). Metode Kualitatif. Bandung: PT. Remaja Rosda Karya.

Nurhasanah, N. (2010). Optimalisasi Peran Mudharabah Sebagai Salah satu Akad Kerjasama Dalam Pengembangan Ekonomi Syari'ah. FH UNISBA XII (3): 286-296.

Pitono. (2020). Provinsi Sumatera Barat dalam Angka. BPS Privinsi Sumatera Barat: Sumber Foto.

Profil MUI Di Akses Dari Https://MUI.Or.Id/Logo-Majelis-Ulama-Mini Pada Tanggal 25 November 2019.

Putri, Siska Elasta. (2018). Pemetaan Jaringan Sosial dalam Organisasi: Studi Pada Distributor Tupperware Unit Simabur Indah di Batusangkar Sumatera Barat. Jurnal Antropologi: Isuisu Sosial Budaya Vol. 20 No. 2 Tahun 2018 (hal 141)

Putri, Siska Elasta. (2020). Upacara Kematian Pada Masyarakat Nagari Taluak Kecamatan Lintau Buo Kabupaten Tanah Datar Dalam Perspektif Hukum Islam. Jurnal Ilmiah Syariah. Vol. 19. No 1. 
106 || Jurnal Intengrasi Ilnu Sygari'ah, Volume 2, Nomor 2, Vei- Igustus 20?

Rahardjo, M,D. (1990). Ensiklopedi Al-Qur'an: Ummah. Jurnal Ulumul Qur'an Studi Ilmu Dan Budaya. Vol. II. No. 5.Jakarta: LSAF, 1990.

Rasyid,A., Dkk. (2016). Peran Kopontren Terhadap Perekonomian Masyarakat Sekitar Pondok Pesantren. Jurnal Iqtisaduna 2(2):1-13.

Ristiyanti, P. (2005). Perilaku Konsumen. Yogyakarta: Andi.

Rosmawati. (2018). Pokok-pokok Hukum Perlindungan Konsumen. Prenadamedia Group: Depok.

Saepudin, P. (1987). Kedudukan Majelis Ulama Ditengah Umat Islam dan Pemerintah. Skripsi. Universitas Indonesia. Jakarta.

Shihab, M,Q. (2007). Pengantin Al-Qur'an. Jakarta: Lentera Hati.

Sleman, Aziz, A. 2013. Etika Bisnis Perspektif Islam. Bandung: Alfabeta.

Sri Handayani. (2012). Aspek Hukum Perlindungan Konsumen dalam Pelayanan Air Bersih pada PDAM Tirtasari Binjai. Jurnal Non Eksakta Volume 4 Nomor 1. Universitas Medan Area. Sumatera Utara.

Sugiyono. (2016). Metodologi Penelitian Kualitatif. Bandung: Alfabeta.

Thobieb A, A. (2003). Bahaya Makanan Haram bagi Kesehatan Jasmani dan Kesucian Rohani. Jakarta: P.T. Al-Mawardi Prima. 